\title{
Studenci polscy i zagraniczni - specyfika ich relacji na przykładzie Uniwersytetu Wrocławskiego
}

Streszczenie: Wzrost liczby studentów zagranicznych na polskich uniwersytetach jest z jednej strony zjawiskiem pożądanym, a z drugiej - stanowiącym wyzwanie dla wszystkich członków środowiska akademickiego. Szczególnie interesujące w kontekście internacjonalizacji uczelni publicznych wydają się relacje cudzoziemców ze studentami polskimi, będące czynnikiem determinującym ich adaptację do nowych warunków edukacyjnych i społecznych.

Niniejszy tekst zawiera wyniki badania ankietowego mającego na celu diagnozę sytuacji studentów zagranicznych oraz ich relacji ze studentami z Polski. W badaniu udział wzięło 73 cudzoziemców realizujących studia po angielsku na Uniwersytecie Wrocławskim w roku akademickim 2016-2017. Zapytano ich m.in. o stosunek do Polaków, intensywność kontaktów z innymi studentami oraz uczestnictwo w życiu uczelni.

Uzyskane odpowiedzi pozwoliły sformułować wniosek, że relacje między studentami zagranicznymi i polskimi są rzadkie, co wynika przede wszystkim z braku okazji do spotkań (studenci cudzoziemscy biorą udział w skierowanych specjalnie do nich zajęciach, zwykle też mieszkają w przeznaczonych dla nich domach studenckich) oraz z bariery językowej.

Słowa kluczowe: studenci zagraniczni, uniwersytety, internacjonalizacja

Internacjonalizacja uczelni wyższych jest zjawiskiem znacząco przybierającym na sile i stanowiącym coraz większe wyzwanie dla społeczności akademickich. Również w Polsce jest ono wyraźnie dostrzegalne - zgodnie z raportem „Studenci zagraniczni w Polsce 2017”, w ciągu ostatniej dekady liczba studentów cudzoziemskich w Polsce wzrosła z blisko 14 tysięcy w roku akademickim 2007/2008 do ponad 65 tysięcy w roku 2017. Jest też coraz częściej dyskutowane zarówno w kontekście pragmatycznych rozwiązań oraz strategii z nim związanych, jak i z perspektywy naukowej. Przedmiotem badań staje się uniwersytet jako miejsce nawiązywania relacji międzykulturowych, przenoszących się następnie na inne poziomy życia społecznego. 
Same wyjazdy zagraniczne w celu podjęcia studiów nie stanowią jednakże żadnego novum - jak zauważa Catherine Montgomery (2010) w książce Understanding the International Student Experience, są one nieodzownym elementem edukacji od wieków, odkąd pierwsi uczeni decydowali się przenosić z miejsca na miejsce, by poszerzać swoją wiedzę.

Aktualnie mają one charakter dalece bardziej zinstytucjonalizowany i należy je uznać za element składowy szerszych ponadnarodowych sił, jakich jak m.in. globalizacja oraz rozwój nowych technologii. Internacjonalizacja jest ponadto na ogół ukazywana jako proces pozytywny i pożądany, a być może nawet trochę idealizowany: ma służyć „tworzeniu otwartego, tolerancyjnego i kosmopolitycznego środowiska akademickiego", a w konsekwencji, jak chcą niektórzy, „budowaniu kulturowych mostów oraz porozumienia potrzebnego do osiągnięcia pokoju na świecie" (Leask, 2010, s. 3). Mniej eksplicytnie wyrażane są bardziej przyziemne aspekty migracji edukacyjnych, takie jak podążający za studentami kapitał, dzięki któremu uczelnie mogą m.in. złagodzić skutki małej liczby rodzimych kandydatów na studia, wynikającej na przykład z niżu demograficznego. Jedno nie ulega wątpliwości - dążenie do przyjmowania coraz większej liczby cudzoziemców w swoje mury jest standardowym elementem funkcjonowania współczesnych uczelni wyższych.

Badacze tego zjawiska wiele miejsca poświęcili relacjom studentów rodzimych z tymi pochodzącymi z innych krajów, koncentrując się m.in. na kwestii wzajemnej percepcji, stereotypów oraz integracji tych dwóch grup. Ze względu na dużą heterogeniczność każdej z nich, część analiz dokonywana jest w odniesieniu do konkretnych narodowości (np. studentów amerykańskich i chińskich) (Brevis, 2013), wyznaniowych lub w zawężeniu do konkretnych kierunków studiów. Warto zauważyć, że badania te bardzo często charakteryzuje niesymetryczność: grupą badaną na ogół są cudzoziemcy, co może sugerować, że to do nich (wyłącznie lub w zdecydowanej mierze) należy odpowiedzialność za proces integracji.

Również w Polsce powstało kilka istotnych prac dotyczących relacji między studentami polskimi a cudzoziemskimi. Wśród najnowszych z pewnością na uwagę zasługuje tom Migracje edukacyjne. Studenci zagraniczni - dwie strony księżyca opracowany pod redakcją Zofii Butrym. Zawiera on wyniki zróżnicowanych pod względem metodologicznym i tematycznym badań dotyczących relacji międzykulturowych na uczelniach w czterech miastach akademickich usytuowanych w czterech krańcach Polski, tj. Lublinie, Olsztynie, Szczecinie i Wrocławiu. Pomimo obietnicy zawartej w tytule zdecydowanie więcej miejsca poświęcono jednak opiniom studentów polskich, wskutek cze- 
go uzyskany obraz jest raczej jednostronny. Na uwagę zasługuje także nieco starsza publikacja Studenci zagraniczni w Polsce: motywy przyjazdu, ocena pobytu, plany na przyszłość autorstwa Cezarego Żołędowskiego.

Zaprezentowane w niniejszym tekście badania wpisują się w nakreśloną powyżej tradycję badania relacji międzykulturowych w kontekście akademickim i dotyczą stopnia integracji studentów polskich oraz zagranicznych w Uniwersytecie Wrocławskim. Warto dodać, że uczelnia ta znajduje się w czołówce polskich uniwersytetów przyjmujących największą liczbę obcokrajowców. Celem przeprowadzonego badania było zdiagnozowanie ogólnej sytuacji cudzoziemców w Uniwersytecie Wrocławskim w kontekście ich relacji ze studentami rodzimymi.

Badania ankietowe przeprowadzone wśród 73 osób zawierały pytania otwarte i zamknięte dotyczące specyfiki kontaktów cudzoziemców ze studentami polskimi oraz wyobrażeń na ich temat. Ankietowanymi byli studenci zagraniczni, którzy w roku akademickim 2016-2017 studiowali na Uniwersytecie Wrocławskim w ramach studiów po angielsku' ${ }^{1}$ Zostali potraktowani jako jedna grupa, nie oznacza to jednak, że zignorowane zostało jej wewnętrzne zróżnicowanie (przede wszystkim narodowościowe). Uznano jednak, że w strukturach Uniwersytetu stanowią oni odrębną grupę, do której skierowane są oddzielne instytucje, wydarzenia, a bardzo często także programy studiów. Uzasadnione jest zatem potraktowanie ich odpowiedzi jako głosu pewnej istotnej, odróżniającej się w strukturach uczelni społeczności. Należy przy tym podkreślić, że badanie to stanowiło wprowadzenie do dalszych analiz z tego zakresu - planowane jest poszerzenie grupy badawczej o studentów rodzimych (będących rzecz jasna równie istotnymi uczestnikami procesu integracji) oraz wykorzystanie metod jakościowych (przede wszystkim wywiadu pogłębionego) do uzyskania szerszego obrazu zjawiska. Niewykluczona jest ponadto dalsza eksploracja tej problematyki z uwzględnieniem podziału na narodowości i kierunki studiów. Niniejszy tekst ma służyć przedstawieniu najważniejszych wstępnych wyników oraz konkluzji.

W badaniu udział wzięło 35 mężczyzn i 38 kobiet pochodzących z 37 krajów z pięciu kontynentów: Afryki, Azji, Europy i obu Ameryk, w wieku od 18 do 37 lat, studiujących na 33 kierunkach na wszystkich poziomach studiów

1 Na Uniwersytecie Wrocławskim duża grupa cudzoziemców realizuje studia w języku polskim i jest traktowana tak samo jak studenci krajowi. Uznano, że ze względu na odmienny charakter ich studiów i relacji z Polakami nie powinni być objęci badaniami ankietowymi, co nie oznacza rzecz jasna, że nie istnieje potrzeba przeprowadzenia takich badań. 
(licencjackie, magisterskie i doktoranckie). Próbę należy więc uznać za bardzo zróżnicowaną, dzięki czemu uzyskano szerokie spektrum odpowiedzi.

Respondenci udzielili odpowiedzi na 25 pytań zamkniętych i otwartych, z których tutaj omówionych zostanie 16. Pierwsza część badań ankietowych dotyczyła podstawowych informacji na temat studentów oraz ich studiów. Wynika z niej, że zdecydowana większość z nich studiuje wyłącznie lub niemal wyłącznie z innymi obcokrajowcami (32\% na zajęciach spotyka tylko obcokrajowców, a 40\% głównie obcokrajowców). Co więcej, tylko 20\% respondentów pozytywnie oceniło swoją znajomość języka polskiego (raczej dobrze, dobrze lub bardzo dobrze), pomimo że $86 \%$ brało udział w kursie języka polskiego ${ }^{2}$.

Studenci zagraniczni spędzają czas we własnym gronie również w miejscu zamieszkania - tylko $6 \% \mathrm{z}$ nich dzieliło pokój lub mieszkanie wyłącznie z Polakami, a 77\% nie mieszkało z nikim z Polski (59\% miało współlokatorów spoza Polski, 9\% nie dzieliło mieszkania ani pokoju z nikim, a 9\% zdecydowało się zamieszkać z osobami ze swojego kraju). 17\% natomiast mieszkało z cudzoziemcami i Polakami jednocześnie. Wypada w tym miejscu uściślić, że aż 75\% wszystkich studentów mieszkało w domach studenckich przeznaczonych właśnie dla cudzoziemców. Mała liczba osób mieszkających z Polakami nie jest więc (a przynajmniej nie wyłącznie) przejawem braku woli studentów zagranicznych - należy ją raczej uznać za efekt procedur związanych z zakwaterowaniem studentów Uniwersytetu Wrocławskiego, stosowanych zresztą również na wielu innych polskich uczelniach.

Druga część badań odnosiła się bezpośrednio do relacji ze studentami z Polski. Pomimo wymienionych wyżej barier - ograniczonego kontaktu większości studentów zagranicznych z Polakami podczas zajęć i w miejscu zamieszkania oraz niewystarczającej znajomości języka polskiego - 40\% respondentów deklaruje, że ma kolegów wśród polskich studentów. Wydaje się jednak, że sytuacji tej nie można ocenić pozytywnie - kolejne $30 \%$ odpowiedziało, że ich kontakty ograniczają się do uczestnictwa w tych samych zajęciach, zaś $\mathbf{1 6 \%}$ zadeklarowało, że nie zna żadnych polskich studentów. $6 \%$ natomiast wybrało opcję „nie jestem zainteresowany poznawaniem studentów z Polski”.

2 Nie należy jednak wyciągać pochopnych wniosków na temat efektywności kursów języka polskiego oferowanych studentom zagranicznym - mogą oni skorzystać z różnych propozycji, w tym bodaj najczęściej wybieraną jest kurs wprowadzający, który trwa jedynie dwa tygodnie. 
O małej intensywności kontaktów studentów z zagranicznych z polskimi świadczą także opinie dotyczące kolejnych, bardziej szczegółowych kwestii. Na pytanie „Z kim zwykle spędzasz czas wolny?” tylko 1\% respondentów odpowiedział, że robi to ze studentami z Polski, a $25 \%$ z Polakami i cudzoziemcami jednocześnie. 74\% zadeklarowało, że na ogół spędza czas wolny z innymi studentami zagranicznymi, z czego 7\% preferowało towarzystwo osób ze swojego kraju. Ponownie więc można stwierdzić, że studenci zagraniczni na Uniwersytecie Wrocławskim najczęściej spędzają czas we własnym gronie.

Trzecia część badań miała na celu wyjaśnienie, co warunkuje relacje studentów polskich z zagranicznymi. Ze względu na złożoność zjawiska obok pytań zamkniętych zawarto w kwestionariuszu ankiety prośbę o krótkie uzasadnienie dokonanego wyboru.

Odpowiedzi na pytanie: „Jakie jest twoje wrażenie związane z poznawaniem polskich studentów?" są bardzo zróżnicowane. 7\% respondentów uznało, że nawiązywanie relacji z Polakami jest trudne, a $25 \%$ „raczej trudne”. Dla $22 \%$ jest to „raczej łatwe” i dla 15\% „łatwe”. Największa grupa - 32\% stwierdziła natomiast, że nie jest to „ani łatwe, ani trudne”. Ambiwalentne odczucia dostrzegalne są także w uzasadnieniach odpowiedzi. Przeważa opinia, że kontakty ze studentami z Polski są zbyt rzadkie, by móc coś więcej o nich powiedzieć. Studenci wielokrotnie zaznaczali, że „rzadko spotykają Polaków”, „nie mieli wielu okazji, by poznać Polaków” czy „zauważyli, że nikt z ich znajomych obcokrajowców nie zawiera przyjaźni z Polakami”. Sytuacja ta jest interpretowana różnorako. Najczęstszym wymienianym powodem małego kontaktu między studentami z Polski i z zagranicy jest brak okazji oraz przestrzeni do wspólnego spędzania czasu. „Nie ma żadnego miejsca, w którym moglibyśmy się spotykać”, „To jest bardzo trudne, bo nie mamy Polaków na naszych zajęciach, a przecież nie zacznę z kimś rozmawiać ot tak na korytarzu”, „uniwersytet nie oferuje zbyt wielu możliwości, np. wspólnych zajęć, dla nas i dla Polaków” „mamy inny rytm życia" - argumentują. Drugim istotnym czynnikiem jest - ich zdaniem - bariera językowa - wielu z nich nie zna języka polskiego, a z drugiej strony studenci polscy nie zawsze chętnie rozmawiają po angielsku, zwłaszcza gdy są w większej grupie (jak zauważają respondenci, albo „nie chcą mówić po angielsku, albo „nie znają tego języka”). Z pewnością z barierą językową związane jest również ogólne, często pojawiające się wrażenie, że studenci z Polski są „trochę zamknięci”, „trochę zimni”, „niekomunikatywni”, „introwertyczni”, „wolą zachować dystans" i „nie wydają się zainteresowani nawiązywaniem znajomości ze studentami międzynarodowymi". Kilkukrotnie wymieniana jest także obserwacja, że i Polacy, i cudzoziemcy wolą spędzać czas oddzielnie, w swoich grupach. 
W kilku przypadkach opinie były zdecydowanie bardziej radykalne: studentom polskim zarzucono negatywny stosunek do cudzoziemców, argumentując, że „unikają cudzoziemców”, „część z nich ma w zwyczaju gapić się na obcokrajowca i dążyć do tego, żeby poczuł się źle”, „są nieprzyjaźni” czy zachowują się agresywnie, gdy ktoś rozmawia w języku innym niż polski. Przywołano także hasło „Polska dla Polaków” i dobitnie wyrażono sąd, że w Polsce jest problem z rasizmem. $Z$ drugiej strony - część studentów ma pozytywne lub bardzo pozytywne zdanie na temat studentów z Polski - opisują ich jako „bardzo przyjaznych”, „miłych”, „pomocnych” oraz „otwartych”. Należy podkreślić, że takie opinie są albo wynikiem bezpośrednich kontaktów (w przypadku tych osób, które mają przyjaciół wśród studentów z Polski), albo ogólnego wrażenia („Nie znam zbyt wielu studentów z Polski, ale wydają się mili”; „nie mamy dużo kontaktu, ale zawsze mi pomagali, kiedy tego potrzebowałam”; „uważam, że bardzo trudno jest poznać Polaków, ale tych kilku, których akurat udało mi się spotkać, było miłych”, „[na zajęciach] nie było jakiejś wielkiej interakcji, [Polacy] rozmawiali z tobą tylko jeśli bezpośrednio się do nich zwróciłeś. Wtedy byli przyjaźni i pomocni”). Wreszcie, są respondenci, którzy uważają, że nawiązywanie kontaktów ze studentami z Polski „zależy od sytuacji” i „od osoby” i nie różni się od relacji z innymi osobami, ponieważ „Polacy są tacy sami jak jakiekolwiek inne nacje, a wszystko zależy od chęci i nastawienia”.

Zapytani o to, jakie jest nastawienie studentów polskich do studentów zagranicznych, cudzoziemcy również udzielili dość zróżnicowanych odpowiedzi. Z jednej strony 16\% oceniło studentów z Polski jako bardzo przyjaznych i otwartych, a kolejne $37 \%$ jako przyjaznych i otwartych, a z drugiej - 23\% wybrało odpowiedź „ani przyjaźni, ani nieprzyjaźni”, co może mieć związek z małą intensywnością kontaktów. 4\% natomiast uznało nastawienie Polaków za nieprzyjazne, a 1\% za nieprzyjazne. Co interesujące, zdaniem 18\% badanych studenci z Polski w ogóle nie są zainteresowani studentami zagranicznymi. Ponownie można więc dostrzec trzy główne grupy odpowiedzi, odzwierciedlające trzy typy relacji między studentami polskimi i zagranicznymi: najczęściej występująca relacja pozytywna lub bardzo pozytywna, rzadka relacja negatywna i bardzo negatywna oraz pewnego rodzaju brak relacji, który można by określić jako „mijanie się” - obie grupy dzielą wspólną przestrzeń, widują się na uczelni i w domach studenckich, nie wytwarza się jednak żadna więź, trudno też mówić o wzajemnym zainteresowaniu.

Tendencja ta jest zauważalna w odpowiedziach na kolejne pytania. Jak można się spodziewać, pomocy w dokonywaniu formalności w uniwersy- 
tecie studenci zagraniczni szukali najczęściej u pracowników Biura Współpracy Międzynarodowej i u swoich zagranicznych znajomych, a w następnej kolejności zwracali się do nauczycieli akademickich. Najrzadziej natomiast szukali wsparcia u swoich rodaków oraz u studentów z Polski. Kwestia ta wydaje się szczególnie interesująca, biorąc pod uwagę, że to właśnie studenci polscy stanowią najlepsze źródło informacji na temat tego, jak radzić sobie z różnego rodzaju formalnościami w uczelni (i z pewnością zdecydowanie lepsze niż inni studenci zagraniczni, zwykle nieznający ani realiów, ani języka polskiego).

Wskazywany wcześniej brak okazji do wspólnych spotkań Polaków i cudzoziemców w kontekście akademickim znajduje odzwierciedlenie w odpowiedziach na pytanie o organizowane w Uniwersytecie wydarzenia, w których studenci zagraniczni wzięli udział. Co znamienne, aż 38\% z nich w ogóle nie brało udziału w żadnych dodatkowych wydarzeniach, natomiast ci, którzy skorzystali z oferty w tym zakresie, w zdecydowanej większości wybrali propozycje skierowane przede wszystkim do studentów zagranicznych. Wymienili m.in. organizowane dla nich wycieczki po mieście i regionie, spotkanie z okazji Świąt Bożego Narodzenia, dni powitalne. Tylko nieliczni dodali takie wydarzenia, jak koncerty i seminaria. Jedynym często wskazywanym wydarzeniem, które nie jest skierowane bezpośrednio do studentów zagranicznych, są Juwenalia. Pozostałe natomiast, tak jak w przypadku zajęć, są okazją do spotkania wyłącznie cudzoziemców.

O ile większość badanych wzięła udział choć raz w dodatkowych wydarzeniach, o tyle ich zdecydowana mniejszość zdecydowała się zaangażować w dodatkową działalność studencką. Tylko $4 \%$ zadeklarowało, że było członkiem organizacji studenckiej, a 10\% udzielało się sportowo i kulturalnie (np. $\mathrm{w}$ teatrze lub chórze). Pozostali nie mieli do czynienia z żadną działalnością studencką.

Badanie zamykają dwa podsumowujące pytania. Pierwsze dotyczy największego wyzwania, które stoi przed studentami zagranicznymi chcącymi nawiązać relacje ze studentami z Polski. Podobnie jak w przypadku wcześniejszych pytań dotyczących tego problemu, najczęściej wskazywano na barierę językową, brak okazji do wspólnych spotkań, a w trzeciej kolejności zbyt małe zainteresowanie ze strony Polaków. Jednocześnie 75\% życzyłoby sobie mieć więcej kontaktów z Polakami, 22\% nie wie, czy chciałoby wchodzić z nimi w częstszą interakcję, a 3\% nie chciałoby tego robić.

Szczególnie interesujące wydają się opinie uzasadniające odpowiedź na to pytanie. Chęć nawiązania bliższej relacji ze studentami z Polski jest w głów- 
nej mierze motywowana potrzebą poznania polskiej kultury. W kontaktach z polskimi studentami cudzoziemcy upatrują zatem możliwość poznania takich elementów życia w Polsce, których sami albo nie są w stanie dostrzec lub pojąć, albo wymagało by to od nich o wiele więcej wysiłku. Charakterystyczne są poniższe wypowiedzi:

- „Chcę poznać lepiej polskich studentów, ponieważ chcę naprawdę dobrze poznać polską kulturę i oczywiście Polacy mogą mi w tym pomóc”.

- „Byłoby miło poznać studentów z Polski i tym samym odkryć polską kulturę jako część całego doświadczenia życia w Polsce”.

- „To wielka szkoda nie znać polskich studentów i nie mieć z nimi kontaktu, będąc w ich kraju, ponieważ my naprawdę chcemy wiedzieć więcej o ich kulturze i zrozumieć ich sposób myślenia”.

- „Dobrze jest znać studentów, którzy są z Polski. Kontakt z nimi otwiera cię na polską kulturę".

- "Są moimi gospodarzami i byłoby ciekawie poznać ich sposób życia”.

Jednocześnie cudzoziemcy uważają, że gdyby znali więcej Polaków, ich życie w nowym kraju byłoby prostsze. Stwierdzają m.in.: „Dobrze byłoby znać więcej Polaków, bo tak wiele razy musieliśmy wszystko odkrywać sami”; „Dla studentów [zagranicznych] lepiej byłoby być bliżej polskich studentów, bo dzięki temu, że są z Polski, mogliby być bardzo pomocni dla cudzoziemców”; „Byłoby świetnie dowiedzieć się więcej o polskiej kulturze. Polskę czasami trudno zrozumieć. Byłoby dobrze mieć okazję do wymieniania się wiedzą. Oni [Polacy] mogliby też udzielić nam wskazówek, gdzie warto pójść, co warto zrobić. I mogliby też nam bardzo pomóc w tłumaczeniu różnych informacji. Zaprzyjaźniłam się z jedną Polką, która pracuje z moim partnerem. Kilka razy uratowała nam życie”. Kilkoro obcokrajowców stwierdza ponadto, że dzięki bliższym relacjom z Polakami mogliby szybciej nauczyć się języka polskiego.

Można więc zauważyć powszechne przekonanie, że bliższy kontakt ze studentami z Polski byłby wartościowym i wzbogacającym doświadczeniem. Uzasadniając odpowiedź na pytanie o chęć nawiązania bliższych kontaktów z Polakami, kilkoro respondentów ogranicza się do wyrażenia swojego smut$\mathrm{ku}$ lub rozczarowania faktem, że w gronie ich znajomych nie ma wielu lub żadnych Polaków. Stwierdzają m.in., że „nie znają żadnego Polaka, którego mogliby uznać za przyjaciela”, i że „to smutne mieć tylko kilku znajomych

3 Warto pamiętać, że angielski "friend" ma znacznie szersze pole semantyczne niż polski „przyjaciel”. Być może należałoby tłumaczyć to słowo raczej jako „kolegę” lub „znajomego". 
Polaków po całym semestrze w Polsce”. Interesująca jest również następująca wypowiedź jednej z bardzo niewielu osób, które uznały, że mają dużo znajomych wśród polskich studentów i nie mają na co narzekać: „Myślę, że moim znajomym studentom zagranicznym przydałoby się częściej wchodzić w interakcję ze studentami z Polski”.

Również w przypadku odpowiedzi na to pytanie respondenci skorzystali z okazji, by przedstawić swoje pomysły na to, jak można by zbliżyć obie grupy studentów. Jeszcze raz proponują, by stworzyć więcej okazji do wspólnych spotkań zarówno podczas zajęć, jak i podczas innych, nieformalnych spotkań. „Jestem przekonana, że gdyby było więcej zajęć, w których udział braliby razem Polacy i cudzoziemcy, znacznie zwiększyłaby się liczba interakcji między studentami zagranicznymi i polskimi" - podobne sugestie pojawiają się kilkukrotnie. Respondenci zwracają też uwagę, że jedynymi Polakami, którzy biorą udział w wydarzeniach, na które zaprasza się studentówcudzoziemców, są ich organizatorzy. „Zwykli studenci nie są zainteresowani udziałem w międzynarodowych wydarzeniach" - przekonują.

Przeprowadzone badanie pozwoliło poznać opinie cudzoziemców na temat ich studiów w Uniwersytecie Wrocławskim oraz nakreślić ogólny obraz ich relacji ze studentami z Polski. Pierwszy wniosek, który można wyciągnąć, dotyczy dużego zróżnicowania doświadczeń - wśród badanych są zarówno studenci, których można uznać za w pełni zintegrowanych z polskim środowiskiem akademickimi, jak i osoby, które obracają się niemal wyłącznie w społeczności obcokrajowców. Można przypuszczać, że to zróżnicowanie jest ściśle związane z dużym stopniem heterogeniczności badanej grupy i tym samym odmiennym dystansem językowym i kulturowym między Polakami a przedstawicielami poszczególnych narodowości. Ta hipoteza wymagałaby jednak weryfikacji w dalszych badaniach, w których dokonano by komparatystyki odpowiedzi z podziałem na narodowość badanych. Jednocześnie można stwierdzić, że na poziomie grupowym (a nie jednostkowych doświadczeń) studenci polscy i zagraniczni żyją raczej obok siebie niż razem, trudno mówić o ich zintegrowaniu, poczuciu wspólnoty, wzajemnym zainteresowaniu. Poza wskazywanymi przez respondentów barierami kulturowymi i językowymi najistotniejszy wpływ na charakter tych relacji mają rozwiązania instytucjonalne. Odrębne programy zajęć kierowane do obu grup, swoista „segregacja” w domach studenckich, osobna oferta zajęć dodatkowych - wszystko to powoduje, że cudzoziemcy rozpoczynający studia w Uniwersytecie Wrocławskim mają niewiele okazji do nawiązania kontaktów ze studentami z Polski, co, jak sami przyznają, skutkuje m.in. ich 
gorszą znajomością sposobu funkcjonowania Uniwersytetu, miasta, języka polskiego oraz kultury polskiej w ogóle. Z drugiej strony - badanie ukazało pewne pozytywne aspekty dotyczące integracji środowiska akademickiego, takie jak duża potrzeba poznawania Polaków ze strony studentów zagranicznych oraz chęć tworzenia okazji do spotkań i współpracy. Można więc mówić o dużym potencjale, który dałoby się wykorzystać, podejmując odpowiednie odgórne i oddolne inicjatywy. W końcu - jak stwierdziła jedna z respondentek - „wszyscy studiujemy w tym samym uniwersytecie, więc powinniśmy być wspólnotą, a nie być sobie obcy".

\title{
Bibliografia
}

Brevis, T. 2013. A History of Higher Education Exchange. New York: Routlege. Leask, B. 2010. „Beside Me Is An Empty Chair”: The student Experience of Internationalization. W: Jones, E. red. Internationalisation and the Student Voice. New York: Routlege, ss. 3-17.

Kawczyńska-Butrym, Z. 2014. Migracje edukacyjne. Studenci zagranicznidwie strony księżyca. Lublin: UMCS.

Montgomery, C. 2010. Understanding the International Student Experience. Basingstoke: Palgrave McMillian.

Raport „Studenci zagraniczni w Polsce 2017”, http://www.studyinpoland.pl/ konsorcjum /index.php?option=com_content\&view=article\&id=14515:raport-stude (10.01.2018).

\section{Polish and foreign students - the specificity of their relations in the case of the University of Wroclaw}

\begin{abstract}
The increase of the number of the international students at Polish universities is a desired phenomenon and at the same time a challenge for whole academic community. What seems especially interesting in the context of the internationalization of public universities is the relation between foreign and Polish students. This relation determines international students' adaptation to a new educational and social conditions.

The article presents the results of a survey that aimed to diagnose the situation of international students and their relation with their Polish colleagues. 73 international students who studied in English at the University of Wrocław in the academic year 2016-2017 took part in the study. They were asked about their
\end{abstract}


attitude towards Poles, the contact with other students, their participation in the university life.

The main conclusion based on the respondents' answers is that thee relations between international and Polish students are rare, to a great degree because both groups have little opportunities to meet (foreigners take part in classes dedicated to them and usually live in international students dormitories) and because of the language barrier.

Keywords: foreign students, universities, internationalization

Translated by Aleksandra Matyja 